\title{
HUBUNGAN SARANA DAN PRASARANA DENGAN KINERJA TENAGA KESEHATAN INSTALASI GAWAT DARURAT (IGD) DI MASA PANDEMI COVID-19
}

\author{
Heni Fa'riatul Aeni ${ }^{1)}$, Muslimin Ali ${ }^{2)}$, Siti Milatul Zanah ${ }^{3)}$ \\ ${ }^{1,2,3}$ Program Studi Kesehatan Masyarakat, STIKes Cirebon \\ Email: henifariatulaeni80@gmail.com
}

Diterima: September 2021, Diterbitkan: Desember 2021

\begin{abstract}
Abstrak
Pencegahan penularan virus Corona-19 dapat ditunjang dengan peningkatan sarana dan prasarana yang memadai sesuai standar yang meliputi Alat Pelindung Diri (APD) terlebih tenaga kesehatan yang menjadi garda terdepan dalam menangani wabah virus ovid-19. Masih ditemukannya tenaga kesehatan IGD di RS Cahaya Bunda yang tidak menggunakan APD secara tidak lengkap diantaranya tidak menggunakan faceshield $30 \%$. Tujuan penelitian untuk mengetahui hubungan sarana dan prasarana dengan kinerja tenaga kesehatan Instalasi Gawat Darurat (IGD) dalam upaya pencegahan dan penularan virus Covid-19 di RSIA Cahaya Bunda Kota Cirebon tahun 2021. Rancangan penelitian ini menggunakan pendekatan kuantitatif desain cross sectional, Populasi ini adalah tenaga kesehatan Instalasi Gawat Darurat (IGD) RSIA Cahaya Bunda Kota Cirebon sejumlah 19 orang sampel diambil dengan teknik total sampling, pengumpulan menggunakan teknik observasi dan wawancara, instrument yang digunakan adalah lembar checklist kuesioner, analisis data menggunakan uji Chi Square. Hasil uji Chi Square menunjukan adanya hubungan yang cukup signifikan antara sarana dan prasarana dengan kinerja dengan diperoleh nilai p-value 0.003 . Saran bagi tenaga kesehatan agar lebih meningkatkan kinerja penanganan kepada pasien, dan menggunakan sarana dan prasarana yang telah di sediakan seoptimal mungkin dalam upaya pencegahan penularan Covid-19.
\end{abstract}

Kata Kunci: Sarana prasarana, Kinerja (Respon Time)

\begin{abstract}
Prevention of the transmission of the Corona-19 virus can be supported by improving adequate facilities and infrastructure according to standards which include Personal Protective Equipment) (PPE), especially health workers who are at the forefront of dealing with the Ovid-19 virus outbreak. There are still Emergency Room health workers at Cahaya Bunda Hospital who do not use PPE incompletely, including not using a 30\% faceshield. The aim of the study is to determine the relationship of facilities and infrastructure with the performance of Emergency Room health workers in efforts to prevent and transmit the Covid-19 virus at RSIA Cahaya Bunda, Cirebon City the year 2021. The design of this study used a quantitative approach with cross sectional design, this population was 19 people from the Emergency Department RSIA Cahaya Bunda, Cirebon City, which obtained 19 samples of data as respondents. is a questionnaire checklist sheet, the data collection method uses primary data and secondary data and data analysis uses the Chi Square test.The results Chi Square test shows that there is a significant relationship between facilities and infrastructure and performance with a p-value of 0.003. Suggestions for health workers to further improve the performance of handling patients, and to use the facilities and infrastructure that have been provided optimally in an effort to prevent the transmission of Covid-19.
\end{abstract}

Keywords: Infrastructure, Performance (Response Time)

\section{PENDAHULUAN}

Pandemi Corona virus 2019 - 2020 atau dikenal sebagai pandemi Covid-19 adalah peristiwa menyebarnya penyakit Corona virus 2019 diseluruh dunia. Penyakit ini disebabkan oleh Corona virus jenis baru yang diberinama SARS-CoV-2
(Gorbalrenya 2020). Wabah Covid-19 pertama kali terdeteksi di daerah Kota Wuhan, Provinsi Hubei, Tiongkok China pada bulan Desember Tahun 2019, dan ditetapkan sebagai pandemik oleh Organisasi Kesehatan Dunia (WHO) pada 11 Maret 2020 (WHO 2020). Hingga 28 
Maret, lebih dari 620.000 kasus Covid-19 telah dilaporkan lebihdari 190 negara dan teritori, mengakibatkan lebih dari 28.800 kematian dan 137.000 kesembuhan (Johns Hopkins University 2020).

Virus SARS-CoV-2 diduga menyebar diantara orang - orang terutama melalui percikan cairan atau cipratan liur (droplet) yang dihasilkan selama batuk(US Centers for Disease Control and Prevention 2019). Percikan ini juga dapat dihasilkan dari bersin, batuk dan berbicara normal. Selain itu, virus dapat menyebar akibat menyentuh permukaan benda yang terkontaminasi dan kemudian menyentuh wajah seseorang. Penyakit Covid-19 paling menular saat orang yang menderitanya memiliki gejala, meskipun penyebarannya mungkin saja terjadi sebelum gejala muncul (Rothan, $\mathrm{H}$. A.; Byrareddy 2020).

Berdasarkan data yang diuraikan oleh Tim Ikatan Dokter Indonesia (IDI) mencatat bahwa angka kematian tenaga kesehatan (nakes) dari Maret sampai 5 Desember 2020 telah menyentuh angka 342 jiwa jumlah tersebut didapat dari jumlah kematian tenaga kesehatan (nakes) seluruh provinsi Indonesia. Angka tersebut dapat mengalami kenaikan jumlah kematian tenaga kesehatan, tercatat dari tim mitigasi IDI per 10 November 2020 yang menyentuh 282 jiwa yang merupakan terdiri dari petugas medis dan kesehatan. Rinciannya dari jumlah 342 jiwa tersebut, antara lain: 192 adalah dokter dan 14 jiwa berprofesi sebagai dokter gigi. Sisa 136 berprofesi sebagai perawat. Jumlah kematian tenaga kesehatan terbanyak terdapat pada provinsi Jawa Timur yang jumlahnya menyentuh angka 77 jiwa dengan rincian 39 dokter, 2 dokter gigi, dan 36 perawat, dan DKI Jakarta menempati posisi kedua dengan 57 tenaga kesehatan. Sedangkan provinsi Jawa Barat menempati urutan ke 4 dengan jumlah tenaga kesehatan yang meninggal dunia berjumlah 38 Jiwa dengan perincian meliputi Dokter berjumlah 17, Dokter Gigi berjumlah 3, dan petugas medis lainnya berjumlah 18 (Badan Pusat Statistik 2020). Risiko keterpaparan terhadap Covid-19 sangat dipengaruhi oleh ketersediaan sarana dan prasarana terutama pemakaian Alat Pelindung Diri.

Pemerintah Kota Cirebon mengumumkan data terakhir untuk kasus Covid-19 di wilayah Kota Cirebon penambahan hingga pertengahan Desember 2020 jumlahnya mencapai dari 1.500 kasus, angka itu jauh lebih tinggi yang di perkirakan Pemerintah Daerah Kota Cirebon. Tingkat penyebaran Kota Cirebon sendiri dapat dikategorikan rentan tertular dikarenakan untuk kasus yang masuk kedalam kontak erat hampir 2 kali lipat dari total yang positif tertular penyakit Covid-19, dengan jumlah kasus kontak erat di Kota Cirebon sebanyak 4074 dengan jumlah karantina 816 dan yang telah dinyatakan selesai karantina sebanyak 3258. Dari data diatas dapat disimpulkan bahwa penularan virus Covid-19 masih sangat riskan dikarenakan masih banyak warga Kota Cirebon yang kurang memperhatikan protokol kesehatan (Pusat Informasi dan Koordinasi Covid-19 Kota Cirebon 2020). Angka kasus Covid-19 di Indonesia masih terus meningkat terutama di wilayah Kota Cirebon. Sedangkan dalam kasus penyebaran Covid-19 di wilayah Cirebon kususnya pada zona Kota Cirebon pertanggal 8 Januari 2021 total keseluruhan yang terjangkit virus Covid19 berjumlah 2315 dan jumlah pasien yang masuk kekatagori suspek berjumlah 440 dengan jumlah yang aktif dalam keperawatan dan isolasi mandiri berjumlah 386 dan yang dinyatakan sembuh 1840 serta untuk jumlah pasien yang meninggal dunia sejumlah 89 orang. Maka itu menimbulkan keresahan di tengah - tengah masyarakat terlebih untuk tenaga kesehatan yang berjibaku dan kontak langsung dengan pasien positif Covid-19 terlebih tenaga kesehatan yang berada di Instalasi Gawat Darurat (IGD) karena menjadi garda terdepan dalam penanganan pasien. Namun para tenaga kesehatan di rumah sakit RSIA Cahaya Bunda Kota Cirebon masih belum optimal 
dalam penanganan pasien Covid-19 karena sarana dan prasarana yang belum sesuai standar termasuk di dalamnya penggunaan alat pelindung diri (APD) di tengah kasus Covid-19 yang semakin meningkat(Pusat Informasi dan Koordinasi Covid-19 Kota Cirebon 2020). Berdasarkan informasi kasus tersebut kebutuhan jumlah alat pelindung diri bagi tenaga kesehatan yang mencakup dalam bagian sarana dan prasarana pelayanan medis di rumah sakit merupakan hal yang paling penting, khususnya diperuntukan oleh tenaga kesehatan rumah sakit yang berada pada garda terdepan yaitu di Instalasi Gawat Darurat (IGD) perlu mendapatkan perhatian khusus terutama dalam ketersediaan sarana prasana dalam penanganan pencegahan penularan virus Covid-19 karena tenaga medis yang berjaga di Instalasi Gawat Darurat (IGD) terus berinteraksi langsung dengan pasien yang terpapar.

Maka selain sumber daya manusia juga sarana dan prasarana pendukung seperti IGD, klinik khusus Covid-19, ruang khusus isolasi, pemeriksaan penunjang radiologi dan laboratorium. Selain itu, Alat Pelindung Diri (APD) merupakan standar wajib. APD yang digunakan harus sesuai level dengan masing-masing indikasi.Yang disiapkan khususnya pada pemakaian alat pelindung diri (APD) yang belum maksimal dalam pengaplikasian pada saat dilapangan dengan merujuk ke dalam faktor ketersediaan. Menurut Sedarmayanti bahwa kinerja dipegaruhi oleh berbagai faktor yakni sikap dan mental, pendidikan, keterampilan, manajemen kepemimpinan, tingkat penghasil, gaji dan kesehatan, jaminan sosial, iklim kerja, sarana dan prasarana, teknologi, dan kesempatan berprestasi (Sedarmayanti 2017). Hasil penelitian Hernika dengan judul Faktorfaktor Yang berhubungan Dengan Kinerja Perawat di Ruang Rawat Inap Di RSUD Cut Nyak Dhien Meulaboh Kabupaten Aceh Barat diperoleh hasil $p$ value 0,015 yang berarti ada hubungan yang bermakna antara fasilitas kerja dengan kinerja perawat (Hernika 2016). Hasil penelitian Ahmad Hanani dengan judul Pengaruh Beban Kerja, Kepuasan, dan Fasilitas Terhadap Kinerja Perawat Di Ruang Perawatan Mawar Lantai II RSU Wisata UIT Makasar diperoleh hasil nilai parameter standarized sebesar 0,383 dengan nilai signifikan 0,002 yang berarti ada hubungan antara fasilitas kerja dengan kinerja petugas kesehatan (Hannani 2016).

Berdasarkan hasil survei awal peneliti, pada tanggal 10 Januari 2021 pada instalasi gawat darurat (IGD) RSIA Cahaya Bunda Kota Cirebon, ditemukan masih terdapat tenaga kesehatan yang masih belum mendapatkan sarana dan prasarana sesuai standar seperti hazmat, masker N95, sepatu boot, pelindung kepala, kacamata sebanyak 30\%. Dari segi kinerja ditemukannya fakta tenaga kesehatan dari segi pelayanan kepada pasien lebih $>5$ menit sebanyak 4 pasien (40\%) dari 10 yang diobservasi.

Dengan melihat latar belakang tersebut peneliti tertarik untuk mengkaji lebih lanjut penelitian yang berjudul "Hubungan Sarana Dan Prasarana Dengan Kinerja Tenaga Kesehatan Instalasi Gawat Darurat (IGD) RSIA Cahaya Bunda Kota Cirebon di masa Pandemi Covid-19”.

\section{METODE PENELITIAN}

Jenis penelitian yang digunakan yaitu kuantitatif dengan pendekatan Crosssectional. Pendekatan Cross Sectional adalah pengambilan data dimana variabel bebas dan variabel terikat yang terjadi pada obyek penelitian di observasi dan diukur dalam waktu yang bersamaan untuk mengetahui ada tidaknya hubungan dari keduanya (Notoatmodjo 2012).

Penelitian ini memberikan analisis korelasi dari hubungan sarana dan prasarana dengan kinerja tenaga kesehatan Instalasi Gawat Darurat (IGD) dalam upaya pencegahan penularan Covid-19 di RSIA Cahaya Bunda Kota 
Cirebon Tahun 2021

Pada penelitian ini variabel bebasnya adalah sarana dan prasarana sedangkan variabel terikatnya adalah kinerja tenaga kesehatan (respon time) di Instalasi Gawat Darurat (IGD) RSIA Cahaya Bunda Kota Cirebon Tahun 2021.

Populasi dalam penelitian ini adalah tenaga kesehatan yang bertugas di Instalasi Gawat Darurat (IGD) RSIA Cahaya Bunda Kota Cirebon Tahun 2021 yang berjumlah sebanyak 19 orang yang terdiri dari dokter jaga dan perawat periode Bulan Februari 2021. Besarnya sampel dilakukan dengan total sampling. Pengumpulan data mengai sarana dan prasaran dilakukan dengan cara angket. Untuk mengukur kinerja dilakukan dengan menggunakan waktu tanggap (respon time) $<5$ menit dihitung sejak pasien datang sampe mendapatkan pelayanan. Analisa data dilakukan dengan uji chisquare.

\section{HASIL DAN PEMBAHASAN}

Tabel 1. Distribusi frekuensi Sarana dan Prasarana Instalasi Gawat Darurat

\begin{tabular}{lcc}
\hline $\begin{array}{l}\text { Sarana dan } \\
\text { Prasarana }\end{array}$ & Frekuensi & $\begin{array}{c}\text { Presentase } \\
\mathbf{( \% )}\end{array}$ \\
\hline $\begin{array}{l}\text { Kurang } \\
\text { memadai }\end{array}$ & 10 & 52,6 \\
Memadai & 9 & 47,4 \\
\hline Total & 19 & 100 \\
\hline
\end{tabular}

Pada tabel 1. menunjukan bahwa sebagian besar responden $10(52,6 \%)$ menyatakan sarana dan prasarana di Instalasi Gawat Darurat (IGD) RSIA Cahaya Bunda kota Cirebon tahun 2021 pada kategori kurang memadai. Sejalan dengan penelitian Hernika diperoleh bahwa fasilitas di ruang rawat inap RSUD Cut Nyak Dien dalam kategori tidak mendukung sebesar 33 (55,9\%) (Hernika 2016).

Menurut Moenir sarana adalah segala jenis peralatan yang berfungsi sebagai alat utama/alat langsung untuk mencapai tujuan. Misalnya: tempat tidur, toilet, tempat sampah, tempat cuci tangan, tempat tunggu pasien, tempat pendaftaran, timbangan dewasa dan timbangan bayi, dan lain - lain. Prasarana adalah segala sesuatu yang membuat sarana tersebut dapat berfungsi. Sedangkan prasarana rumah sakit meliputi persyaratan, ventilasi, listrik, air bersih, drainase, pengolahan limbah, sistem proteksi terhadap bahaya kebakaran, sistem komunikasi, sistem tata suara, pencahayaan, sistem gas medis, sarana transportasi vertikal (ramp dan tangga serta lift), dan sebagainya (Moenir 2006). Berdasarkan hasil wawancara peneliti bahwa sarana dan prasarana yang kurang memadai di Instalasi Gawat Darurat (IGD) RSIA Cahaya Bunda kota Cirebon tahun 2021 diantaranya; di ruang alat medis tidak tersedianya hazmat, sepatu boot, kacamata pelindung, dan pelindung kepala. Kelengkapan Alat pelindung Diri (APD) merupakan bagian sarana dan prasarana yang sangat penting terutama dimasa pandemi covid-19. Selain itu, belum tersedia ruangan persiapan bencana massal, ruang gas medis, gudang kotor, ruang tindakan bedah, ruang diskusi, ruang resusitasi. Adanya 9 responden yang menyatakan bahwa sarana dan prasarana sudah memadai kemungkinan karena responden tidak mengetahui standar sarana dan prasarana yang sudah ditentukan KepMenkes RI No 856/Menkes/SK/IX/2009. Selain itu banyak hal lain juga yang memungkinkan persepsi yang berbeda pada responden diantaranya karena keterbatasan waktu sehingga terburu-buru saat mengisi kuesioner, dan tipe Rumah Sakit.

Tabel. 2 Distribusi frekuensi Kinerja Tenaga Kesehatan

\begin{tabular}{lcc}
\hline Kinerja & Frekuensi & $\begin{array}{c}\text { Persentase } \\
(\%)\end{array}$ \\
\hline Kurang Baik & 7 & 36,8 \\
Baik & 12 & 63,2 \\
\hline Total & 19 & 100 \\
\hline
\end{tabular}

Berdasarkan tabel 2 menunjukan bahwa sebagian besar responden 12 (63,2\%) memiliki kinerja dalam kategori baik di 
Instalasi Gawat darurat (IGD) RSIA Cahaya Bunda kota Cirebon tahun 2021. Sejalan dengan hasil penelitian Magdalena diperoleh bahwa sebagian besar responden mendapatkan respon time yang sesuai standar sebanyak 90,8\%. Hal ini menunjukkan bahwa kinerja perawat (respon time) baik. Berbeda dengan hasil penelitian Hernika dimana diperoleh bahawa kinerja responden sebagian besar pada kategori kurang baik sebanyak 32 $(54,2 \%)$ (Hernika 2016).

Kinerja adalah hasil kerja secara kualitas dan kuantitas yang dicapai oleh seorang pegawai dalam melaksanakan tugasnya sesuai dengan tanggung jawab yang diberikan kepadanya (Mangkunegara 2015).

Pada penelitian ini pengukuran kinerja dilakukan dengan menggunakan respon time. Menurut Suharteti, respon time adalah kecepatan dalam menangani klien(Akrian N Tumbuan, Lucky Kumaat 2015). Pelayanan pasien gawat darurat adalah pelayanan yang memerlukan pelayanan segera yaitu cepat, tepat dan cermat untuk mencegah kematian dan kecacatan (Basoeki, A.P., Koeshartono, Rahardjo. E. 2008). Respon time dipengaruhi oleh beberapa hal diantaranya, jumlah tenaga, sarana dan prasarana, pengetahuan atau pengalaman perawat (Eko 2015). Hasil penelitian mengenai kinerja (respon time) yang kurang baik ditemukan lebih kepada kurangnya kecepatan dalam penanganan pasien salah satunya akibat keterbatasan jumlah bad.

Tabel 3. Hubungan Sarana dan Prasarana dengan Kinerja (Response Time)

\begin{tabular}{lccccc}
\hline \multirow{2}{*}{$\begin{array}{l}\text { Sarana } \\
\text { dan }\end{array}$ Prasarana } & \multicolumn{3}{c}{ Kinerja } & \multirow{2}{*}{$\begin{array}{c}P \\
\text { Kurang } \\
\text { baik }\end{array}$} & \multicolumn{2}{c}{ Baik } & value \\
\cline { 2 - 4 } & $\mathrm{n}$ & $\%$ & $\mathrm{n}$ & $\%$ & \\
\hline $\begin{array}{l}\text { Kurang } \\
\text { baik }\end{array}$ & 7 & 70,0 & 3 & 30,0 & \\
Baik & 0 & 0,0 & 9 & 75,0 & 0,003 \\
\hline Total & 7 & 36,8 & 12 & 63,2 & \\
\hline
\end{tabular}

Berdasarkan tabel 3. menunjukan bahwa terdapat $7(70,0 \%)$ responden mengatakan sarana dan prasarana dalam kategori kurang baik memiliki kinerja kurang baik. Sedangkan $9 \quad(75,0 \%)$ responden mengatakan sarana dan prasarana dalam kategori baik memiliki kinerja baik.

Hasil uji chi-square diperoleh $p$ value 0,003 $(\mathrm{p}<0,05)$, maka dapat disimpulkan bahwa terdapat hubungan antara sarana dan prasarana dengan kinerja tenaga kesehatan Instalasi Gawat Darurat (IGD) di RSIA Cahaya Bunda Kota Cirebon tahun 2021. Sejalan dengan hasil penelitian Hernika dengan judul Faktor-faktor Yang berhubungan Dengan Kinerja Perawat di Ruang Rawat Inap Di RSUD Cut Nyak Dhien Meulaboh Kabupaten Aceh Barat diperoleh hasil $p$ value 0,015 yang berarti ada hubungan yang bermakna antara fasilitas kerja dengan kinerja perawat (Hernika 2016). Hasil penelitian Ahmad Hanani dengan judul Pengaruh Beban Kerja, Kepuasan, dan Fasilitas Terhadap Kinerja Perawat Di Ruang Perawatan Mawar Lantai II RSU Wisata UIT Makasar diperoleh hasil nilai parameter standarized sebesar 0.383 dengan nilai signifikan 0,002 yang berarti ada hubungan antara fasilitas kerja dengan kinerja petugas kesehatan (Hannani 2016). Begitu juga dengan hasil penelitian Desak Nyoman Suartini dimana hasil penelitiannya menunjukkan bahwa terdapat hubungan yang bermakna antara sarana dan prasarana dengan standar pelayanan minimal di ruang instalasi gawat darurat (Desak, Nyoman Suartini; Andi, Syamsul Bachru Jamal; Anas 2020).

Menurut Simanjutak faktor yang mempengaruhi kinerja seseorang adalah kualitas dan kemampuan pegawai, sarana pendukung, dan supra sarana (yang berkaitan dengan kebijakan). (Widodo, 2015) Sarana dan prasarana yang memadai akan mendukung kinerja seorang pegawai menjadi lebih baik.

Karena kinerja pegawai kesehatan pada penelitian ini diukur berdasarkan respon time. Faktor yang mempengaruhi respon time adalah kompetensi perawat, sarana 
dan prasaran, pengetahuan dan keterampilan, kecepatan pelayanan, ketepatan pelayanan (Eko Widodo, 2015).

Hasil penelitian menunjukkan terdapatnya hubungan antara sarana dan prasaran dengan kinerja tenaga kesehatan di Instalasi Gawat Gawat Darurat (IGD) RSIA Cahaya Bunda Kota Cirebon sejalan dengan teori yang dikemukan oleh Gibson. Kinerja yang kurang baik (kecepatan respon time) pada tenaga kesehatan di Instalasi Gawat Darurat RSIA Cahaya Bunda Kota Cirebon dipengaruhi oleh kurang memadainya sarana prasarana yang tersedia seperti keterbatasan jumlah bad, yang membuat kinerja (respon time) tenaga kesehatan di ruang IGD menjadi tidak sesuai dengan ketentuan $(<5$ menit $)$.

\section{SIMPULAN}

Hasil uji chi-square diperoleh $\mathrm{p}$ value $0,003(\mathrm{p}<0,05)$, artinya terdapat hubungan antara sarana dan prasarana dengan kinerja tenaga kesehatan Instalasi Gawat Darurat (IGD) di RSIA Cahaya Bunda Kota Cirebon tahun 2021. Semakin memadai sarana dan prasarana yang tersedia, maka akan semakin baik pula kinerja (time respon) tenaga kesehatan di Instalasi Gawat Darurat (IGD).

\section{UCAPAN TERIMAKASIH}

Terima kasih kepada pihak Pimpinan RS Cahaya Bunda Kota Cirebon atas ijin dan kerjasamanya untuk melakukan penelitian serta kepada tenaga kesehatan Instalasi Gawat Darurat yang telah bersedia menjadi Responden. Untuk STIKes Cirebon penulis ucapkan terimakasih atas suport yang diberikan.

\section{DAFTAR PUSTAKA}

Akrian N Tumbuan, Lucky Kumaat, Reginus Malara. 2015. "Hubungan Response Time Perawat Dengan Tingkat Kecemasan Pasien." Jurnal Keperawatan 3(2):1-8.

Badan Pusat Statistik. 2020. Data Covid-19. Basoeki, A.P., Koeshartono, Rahardjo. E.,
Wirjoatmodjo. 2008. Penanggulangan Penderita Gawat Darurat Anestesiologi \& Reanimasi. Surabaya: FK UNAIR.

Desak, Nyoman Suartini; Andi, Syamsul Bachru Jamal; Anas, Budi. 2020. "Implementasi Standar Pelayanan Minimal Di IGD RSUD I Lagaligo Wotu." Health Care: Jurnal Kesehatan 9(2):93-99.

Eko, Widodo; Wahyu Rima Agustin; Wahyuningsih Safitri. 2015. "Hubungan Response Time Perawat dalam memberikan pelayanan dengan kepuasan pelanggan di IGD RS. Panti Waluyo Surakarta." STIKes Kusuma Husada Surakarta.

Gibson, J L., Ivancevich, J. M. 1997. "Organisasi : Perilaku, Struktur, Proses." in 8. Jakarta: Binarupa Aksara.

Gorbalrenya, A. E. 2020. Severe Acute Respiratory Syndrome-Related Coronavirus: The Species and Its Viruses - a Statement of the Coronavirus Study Group.

Hannani, Ahmad. 2016. "Pengaruh Beban Kerja, Kepuasan, Dan Fasilitas Terhadap Kinerja Perawat Di Ruang Perawat Mawar Lantai II RSU Wisata UIT Makassar." Jurnal Mirai Management 1(2).

Hernika. 2016. "Faktor-Faktor Yang Berhubungan Dengan Kinerja Perawat Di Ruang Rawat Inap RSUD Cut Nyak Dhien Meulaboh Kabupaten Aceh Barat Tahun 2015." Universitas Teuku Umar Meulaboh.

Johns Hopkins University. 2020. Coronavirus COVID-19 Global Cases.

Mangkunegara, Anwar Prabu. 2015. Manajemen Sumber Daya Manusia. Bandung: Remaja Rosdakarya.

Moenir. 2006. Manajemen Pelayanan Umum Di Indonesia. jakarta: Bumi Aksara.

Notoatmodjo, Soekidjo. 2012. Metodologi 
Penelitian Kesehatan. Jakarta: PT Rineka Cipta.

Pusat Informasi dan Koordinasi Covid-19 Kota Cirebon. 2020. Data Covid-19.

Rothan, H. A.; Byrareddy, S. N. 2020. "The Epidemiology and Pathogenesis OfCoronavirus Disease (COVID-19) Outbreak." Journal of Autoimmunity.

Sedarmayanti. 2017. Perencanaan Sumber Daya Manusia Untuk Meningkatkan Kompetensi, Kinerja, Dan Produktivitas Kerja. Bandung: PT Refika Aditama.

US Centers for Disease Control and Prevention. 2019. Symptoms of Novel Coronavirus.

WHO. 2020. General's Opening Remarks at the Media Briefing on COVID- 19 11 March 2020. 